\title{
THE MEANING OF ACOSMIA IN ARISTOTLE, POLITICS II, 1272b1-16
}

\author{
Amarande Laffon ${ }^{1}$ \\ Université Paris IV Sorbonne
}

RESUMEN

La palabra griega acosmia, en oposición a cosmos, se refiere al desorden y a la mala conducta a nivel físico, moral o social. En Política de Aristóteles II, 1272b1-16, la palabra acosmia es usada en la descripción de las instituciones cretenses. En este contexto particular, se han dado interpretaciones contrapuestas para el término acosmia, en la medida en que Cosmos es también un título de magistrado en Creta. Examinaré aquí las cuestiones filológicas y filosóficas planteadas por este uso puntual de "acosmia".

Palabras clave: Acosmia, anarchia, vacío de poder, desorden, Cosmi.
Recibido: 16.05.2018 - Aceptado: 30.07.2018

\begin{abstract}
The Greek word acosmia, in opposition to cosmos, refers to disorder and bad behavior, on a physical, moral or social level. In the Politics of Aristotle II, 1272b1-16, the word acosmia is used in the description of Cretan institutions. In this particular context, conflicting interpretations have been given of the term acosmia, as cosmos is also a title of magistrate in Crete. I will examine here the philological and philosophical issues raised by this particular use of "acosmia".
\end{abstract}

Keywords: Acosmia, anarchia, power-vacuum, disorder, Cosmi.

\footnotetext{
1 a.laffon@yahoo.fr
} 


\section{INTRODUCTION}

Book II of Aristotle's Politics is devoted to the critical examination of constitutions considered as the best ones. After having examined the constitution of Sparta in Chapter IX, Aristotle presents the Cretan constitution in Chapter X. He correlates and compares the institutions of the two regimes. Thus he equates the ephors in Sparta and the Cosmi in Crete. However, Aristotle estimates that the institution of the Cosmi is inferior to the one of the ephors. Indeed, as he indicates, all citizens in Sparta are eligible to this office. Therefore, the people participate in supreme power and wish to maintain the constitution ${ }^{2}$ whereas in Crete only a few families have a right to lay claim to the office of Cosmi, so the people are excluded from power. All the more since the Elders ${ }^{3}$ forming the Council ( $\beta$ ov $\lambda$ í) are chosen only among those who have been Cosmi. ${ }^{4}$ The oligarchic nature of this institution makes the office extremely unstable. ${ }^{5}$ The explanatory passage that follows raises important philological problems. I was led to examine it while studying the phenomenon of anarchia ( $\alpha v \alpha \rho \chi^{\prime} \alpha$, anarchy $)^{6}$ in its institutional meaning, that is, the vacancy of the office of archon, which is attested in Athens and Thasos. ${ }^{7}$ Indeed, Aristotle uses the term a-cosmia ( $\dot{\alpha}-$ $\left.\left.\kappa o \sigma \mu i^{8}\right)^{8}\right)$ that may refer, on the model of an-archia ( $\left.\alpha \nu-\alpha \rho \chi^{i} \alpha\right)$, to the vacancy of the office of Cosmos. ${ }^{9}$

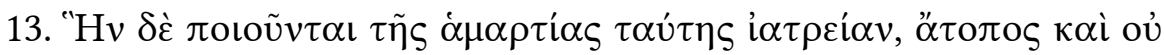

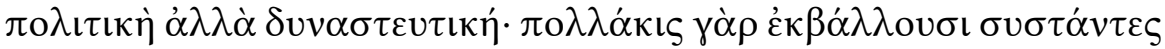

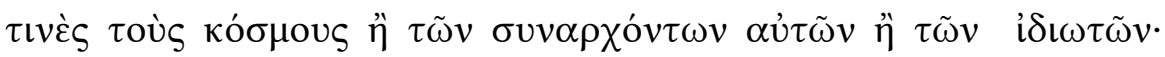

${ }^{2}$ Aristotle, Politics, II 10, 1272a31-33, cf. II 9 21, $1270 \mathrm{~b} 20$.

${ }^{3}$ Aristotle, Politics, II 10, 1272a35-39.

${ }^{4}$ Aristotle, Politics, II 10, 1272a33-35.

5 On the magistracy of Cosmi, cf. Willetts 1955, 1967; Perlman 1992, 2002; Link 1994, 2003; Gehrke 1997; Ruzé 1997; Papakonstantinou 2002; Guizzi 2005; Chaniotis 2005.

${ }^{6} \mathrm{My} \mathrm{PhD}$ dissertation completed in Paris IV Sorbonne University deals with anarchy in Ancient Greece from Archaic to Hellenistic period ("L'anarchie en Grèce ancienne").

7 Aristotle, Athenian Constitution, XIII, 1-2, Xenophon, Hellenics, II, 3, 1-2, Pouilloux 1954, p.263-268.

${ }^{8}$ LSJ: "disorder, extravagance, excess, disorderliness, absence of kosmos, chaos, abeyance of kosmoi".

9 This particular meaning, nowhere else attested, has been generally adopted from the $19^{\text {th }}$ century onwards but rarely specifically commented: Bernays 1872, p.115 ("die Suspension der Kosmenbehörde"), Newman 1887 ("an abeyance of the magistracy of the Cosmi"), Aubonnet 1960 ("la suspension de cette magistrature"), Tricot 1962 ("la vacance de la charge de cosme"), Pellegrin 1990 ("la suspension de la magistrature des cosmes"), Curnis \& Pezzoli 2012 ("la sospensione della carica dei cosmi"). 


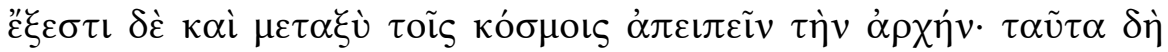

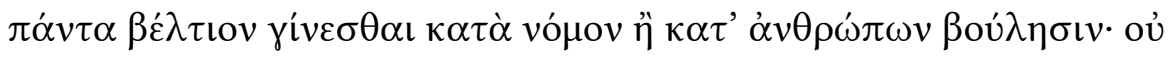

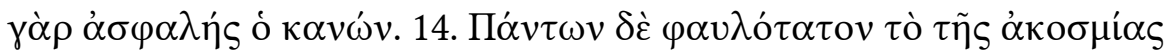

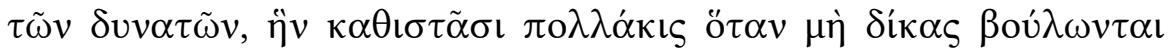

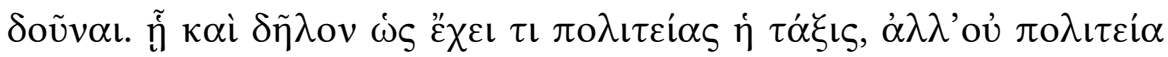

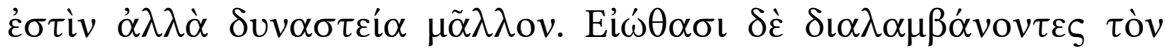

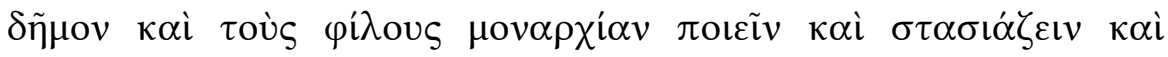

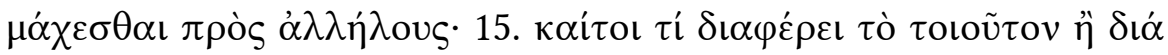

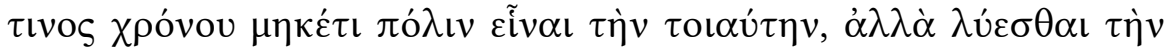

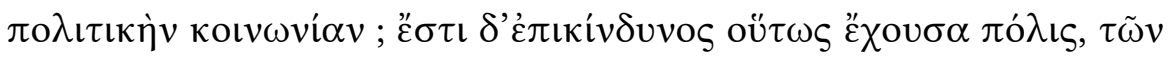

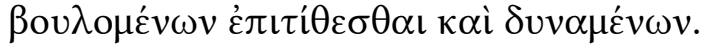

Aristotle, Politics, II, 1272b1-16 ${ }^{10}$

To begin with, I will present the various kinds of interruptions in the office tenure described first by Aristotle. Then I will examine the use of the term acosmia through referring in particular to the interpretations of the passage in Medieval and Renaissance translations and commentaries of Aristotle's Politics. Finally, I will conclude with the consequences of acosmia on the Cretan regime through replacing this passage within the overall perspective of Aristotle's work.

\section{THE SUSPENSION OF THE OFFICE OF COSMI}

The access to the office of Cosmi and consequently to the Council of Elders is restricted to a few prominent and ancient families thus concentrating a very great power in their hands. This very selective method of appointment is problematical. Aristotle regards it as an hamartia ( $\alpha \mu \alpha \rho \tau i \alpha$, "error, mistake, defect") and presents the surprising solutions - referred to as iatreia (i $\alpha \tau \rho \varepsilon i \alpha$, "remedy") - that the Cretans adopt:

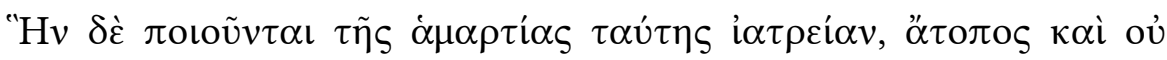

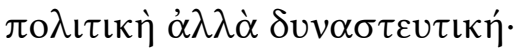

The remedy they give to this error is strange; it is not political but dynastic.

The "remedy" consists in the suspension of the power of the Cosmi in two forms: expulsion and resignation.

${ }^{10}$ Aubonnet 1960. I give a personal translation of the text under examination throughout the article. 


\section{a. The first solution: expulsion}

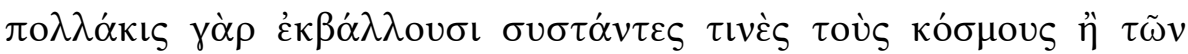

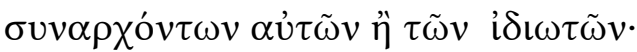

Indeed, often some of their colleagues themselves or some private individuals form a coalition and expel the Cosmi.

A conspiracy forces the Cosmi out of power. It is fomented by Cosmi in charge or private citizens who remove Cosmi from office by force, leaving, as it seems, the city without any Cosmi. This phenomenon could be the consequence of conflicts between prominent families who share the office and/or with the families which are excluded from it. A parallel can be established with a passage in Aristotle's Athenian Constitution, XIII, 1-2. Soon after the reforms of Solon, the eponymous archon Damasias is expelled

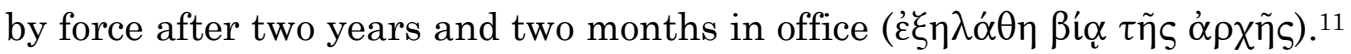
The lot of the other archons is not indicated.

\section{b. The second solution: resignation}

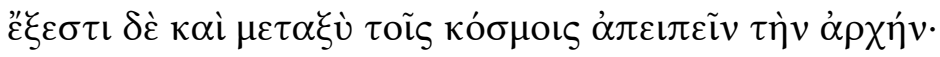

But it is also possible for the Cosmi to quit their office in the meantime.

In this case, the Cosmi abandon themselves their office during the term

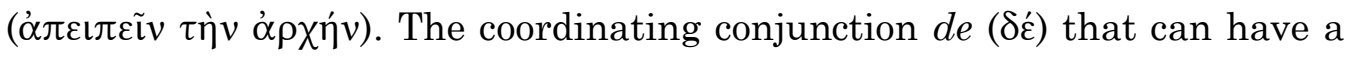
contrasting function and the adverb metaxu ( $\mu \varepsilon \tau \alpha \xi \dot{v}$ ) ("but in the meantime") suggest that Cosmi under pressure prefer to desist themselves before being chased away.

One may ask if resignation could be also a way for Cosmi to escape prosecution, payment of fine or accountability at the end of term. Nevertheless, it is not, in my opinion, Aristotle's perspective, because he emphasizes in particular the incorruptibility of these magistrates (1272a40). According to W. L. Newman, ${ }^{12}$ resignation before the completion of the mandated term of office was not usually authorized in Greece. There are indeed only rare examples and it is difficult to determine if it was a forced dismissal or a voluntary resignation.

\footnotetext{
${ }^{11}$ Mathieu \& Haussoullier 1985.

12 Newman 1887, 357.
} 


\section{c. Aristotle's commentary}

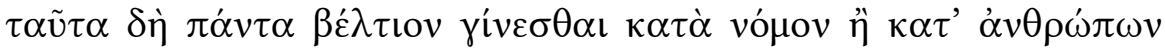

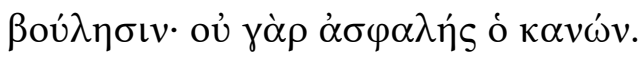

Certainly, all this would better happen according to law than men's opinion. Indeed the rule is unsafe.

Both cases mentioned previously ( $\tau \alpha \tilde{u} \tau \alpha \delta \dot{\eta} \pi \alpha \dot{\alpha} \tau \alpha)$ are, according to

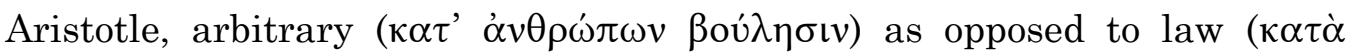
vó $\mu$ ov). Law is something sure and permanent whereas men's goodwill is uncertain and changeable. The principle (ó $\kappa \alpha v \omega \dot{\omega} v$ ) which consists in following men's opinion cannot be a law (a vó $\mu$ os).

The commentary resumes to confirm it, after a factual illustration, the idea expressed in the introductory sentence that presented this remedy as atopos (" $\tau$ о $\pi \circ \varsigma$, "out of place, strange, extraordinary"), and dynasteutike

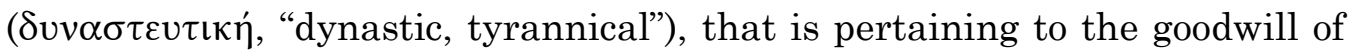

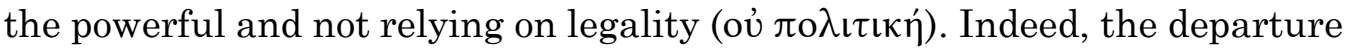
of the Cosmi is not legally regulated and depends upon the goodwill of some individuals. Moreover, according to Aristotle, the office of magistrate is an obligation for those who deserve it: in his analysis of the Spartan regime, he indicates that the most deserving citizen must hold office, whether he wants it or not. ${ }^{13}$

Thus expulsion by force and voluntary resignation appear to be two remedies, which are not constitutional, to the excessively oligarchic method of appointment, by preventing the same individuals to keep a power too great for too long. But Aristotle doesn't stop there and presents a third phenomenon: the acosmia.

\section{ACOSMIA : PHILOLOGICAL, TRANSLATION AND INTERPRETATION ISSUES}

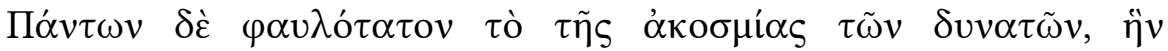

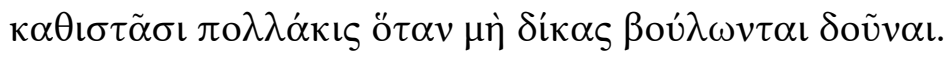

The worst of all is the acosmia of the powerful that they establish often when they do not want to suffer punishment.

This is the text adopted by the majority of editors today ${ }^{14}$ but three main versions of this sentence have been transmitted in manuscripts related to

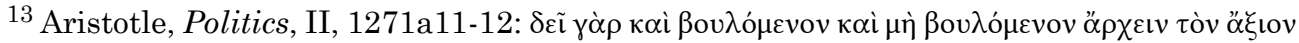

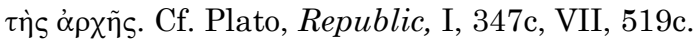

14 Bekker 1831, Newman 1887, Ross 1957, Aubonnet 1960, Dreizehnter 1970, Curnis \& Pezzoli 2012.
} 
variations on the term tōn dunatōn ( $\tau \tilde{\omega} v \delta v v \alpha \tau \tilde{\omega} v)$ and its position, after tēs

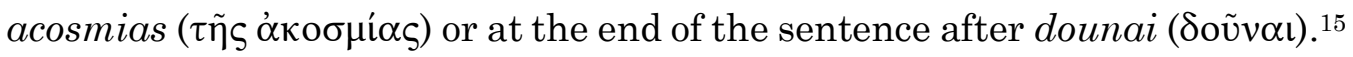

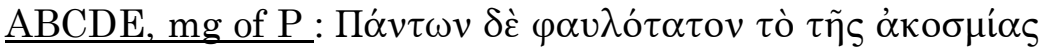

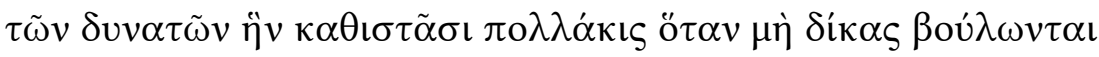

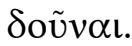

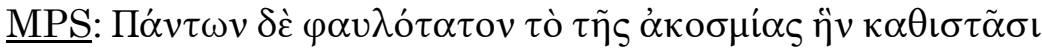

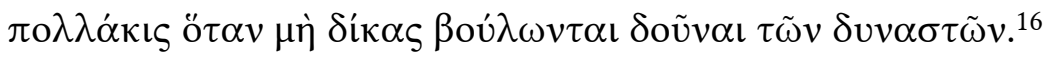

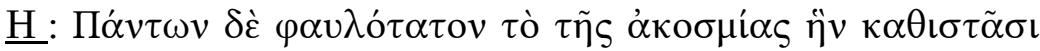

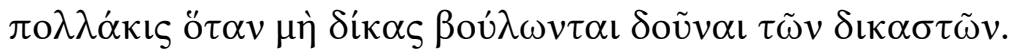

What is the meaning of acosmia? Is it another remedy or does Aristotle rephrase what he said previously? Why does he qualify this process as the worst? To give an answer to these questions, I studied the uses of the word acosmia in Greek literary sources and I traced the history of the interpretations of this passage through translations and commentaries made since the rediscovery of the Politics in the $13^{\text {th }}$ century until the $17^{\text {th }}$ century. ${ }^{17}$

\section{a. Acosmia as "disorder" or "misbehavior"}

On the one hand, acosmia has been understood as "disorder" or "misbehavior". This interpretation prevailed from the $16^{\text {th }}$ to the $19^{\text {th }}$ century.

15 Two families of medieval manuscripts have been identified by editors, transmitting a text that was already presenting several variants since Antiquity. One family (Susemihl's $\Pi^{2}$ ) contains various manuscripts among which the $14^{\text {th }}$ century ms A (ca 1360/80) copied in Constantinople is probably the oldest (with $13^{\text {th }}-15^{\text {th }}$ (?) century $\mathrm{ms} \mathrm{B}$ and $15^{\text {th }}$ century mss $\mathrm{C}$, $\mathrm{D}$ and E). The other family (Susemihl's $\Pi^{1}$ ) contains 3 Italian manuscripts (the older P (ca 1460/80) and the twin $15^{\text {th }}$ century mss $\mathrm{M}$ and S). The ms H stands apart: it seems to show a state of the tradition preceding the division between the 2 main families which was relatively late. Cf. Dreizehnter 1962 and 1970, Besso \& Curnis 2011, 3-55. NB: ms A Dreizehnter/Curnis $=\mathrm{Q}$ Aubonnet $=\mathrm{P}^{2}$ Susemihl $; \mathrm{ms}$ B Dreizehnter $/$ Curnis $=\mathrm{R}$ Aubonnet $=\mathrm{P}^{3}$ Susemihl.

16 This word order is adopted by Susemihl 1894 and Goold 1932 with an emendation by

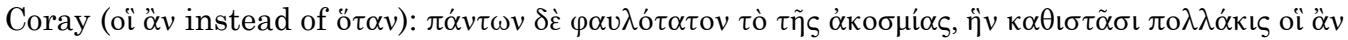

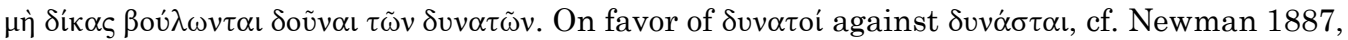
ad loc. The $13^{\text {th }}$ century Latin translations of W. of Moerbeke (cf. infra) present the same word order as $\Pi^{1}$. Two translations attributed to W. of Moerbeke remain, one incomplete (Book I II, 1273a30) dated 1260-1264 (G.i.) and a second one complete (G.). Following Besso \& Curnis 2011, 36-37, G. and G.i. are correlated respectively to $\Pi^{1}$ and $\Pi^{2}$ at a moment when the differences between the two families were not as much marked as attested by manuscripts.

17 On the earliest translations of Aristotle's Politics and their role in Medieval and Renaissance thought, cf. Schmitt 1992, Lanza 2013, Schütrumpf 2014. 


\begin{tabular}{|c|c|}
\hline $\begin{array}{l}\text { Jacques Le } \\
\text { Fèvre d'Etaples, } \\
1506\end{array}$ & $\begin{array}{l}\text { Quia omnium deterrima turbatio : ipsorum potentum ab Cosmatus } \\
\text { dignitate depositio... }{ }^{18}\end{array}$ \\
\hline $\begin{array}{l}\text { Joachim Périon, } \\
1542\end{array}$ & $\begin{array}{l}\text { Omnium autem vitiorum, nullum neque foedius neque deterius ea } \\
\text { confusione... }{ }^{19}\end{array}$ \\
\hline $\begin{array}{l}\text { J. G. Sepúlveda, } \\
1548\end{array}$ & Sed vincit omnem pravitatem ea rerum perturbatio... ${ }^{20}$ \\
\hline $\begin{array}{l}\text { Pietro Vettori, } \\
1552\end{array}$ & $\begin{array}{l}\text { Pessimum autem omnium est perturbatio reipublicae... } \\
\text { perturbationem \& confusionem omnium rerum... }{ }^{21}\end{array}$ \\
\hline $\begin{array}{l}\text { Denis Lambin, } \\
1567\end{array}$ & $\begin{array}{l}\text { Omnium aut remediorum pessimum est magistratus huius } \\
\text { amplissimi vacuitas totiusque reipublicae status perturbatio... }{ }^{22}\end{array}$ \\
\hline $\begin{array}{l}\text { Louis Le Roy, } \\
1568\end{array}$ & Mais le plus grand mal qui y soit, est le desordre... ${ }^{23}$ \\
\hline $\begin{array}{l}\text { J. Camerarius, } \\
1581\end{array}$ & licentiam potentium ${ }^{24}$ \\
\hline $\begin{array}{l}\text { Antonio } \\
\text { Montecatini, } \\
1594\end{array}$ & $\begin{array}{l}\text { Translation: Omnium vero pessimum illud est, quod ad } \\
\text { perturbationem potentum attinet... Commentary: Peccatum omnium... } \\
\text { deterrimum, est illa rerum civitatis, statusque reipublicae conturbatio, } \\
\text { ac confusio [...] turbae illae potentum [...] perturbatio totius civitatis, } \\
\text { statusque reipublicae [...] rerum civitatis, statusque reipublicae } \\
\text { perturbationem. Vertere etiam possem immodestiam, ac } \\
\text { petulantiam potentum, ex qua turbae nascuntur. Perturbationem } \\
\text { autem potentum intellige, ab potentibus creatam, ut declarant verba } \\
\text { sequentia [...] turbas movent... }\end{array}$ \\
\hline $\begin{array}{l}\text { Pierre de La } \\
\text { Ramée, } 1601\end{array}$ & $\begin{array}{l}\text { Ex omnibus autem peccatis nullum deterius, neque foedius est ea } \\
\text { reipub. perturbatione, quae à locupletibus \& potentibus cum iudicia } \\
\text { disturbant, excitatur. }{ }^{26}\end{array}$ \\
\hline
\end{tabular}

18 In hoc libro contenta: Politicorum [Aristotelis] libri octo; commentarii [Jacobi Fabri Stapulensis in eosdem]; Economicorum duo; Commentarii [Fabri]; Hecatonomia septem; Economiarum publicarum unus; Explanationes Leonardi [Aretini] in Oeconomica duo, Parisiis, ex officina Simonis Colinaei, 1543.

19 Aristotelis, De republica, qui Politicorum dicuntur libri VIII, Joachimo Perionio Benedictino Cormoeriaceno interprete, editio tertia, Parisiis, ex typ. Thom. Richardi, 1557.

20 Aristotelis Stagiritae, De Republica lib. VIII. Interprete et enarratore Jo. Genesio Sepulveda Cordubensi, quibus iam adiecti sunt Kyriaci Strozae de Repub. lib. duo: videlicet, nonus et decimus, graece conscripti, nunc ab eodem Stroza latinitate donati. Coloniae Agrippinae, in officina Birckmannica sumptibus Arnoldi Mylij, 1601.

21 Petri Victorii, Commentarii in VIII. Libros Aristotelis, De Optimo statu civitatis, Florentiae, in officina Iuntarum, Bernadi Filiorum, 1576.

${ }^{22}$ Aristotelis, Politicorum libri octo ex Dion. Lambini et P. Victorii interpretationib. Puriss. Graecolatini, Theod. Zuingeri argumentis atque scholiis, tabulis quinetiam in tres priores libros illustrati: Victorii commentariis perpetuis declarati, Basileae, Eusebii Episcopii opera ac impensa, 1582.

${ }^{23}$ Les Politiques d'Aristote, traduittes de Grec en François, par Loys Le Roy dit Regius, 22 décembre 1575, Michel de Vascosan.

24 Camerarius Joachim, Politicorum et oeconomicorum Aristotelis: interpretationes et explicationes accuratae, Francofurti, apud Andream Wechelum [1581].

25 Aristotelis, Politicorum, hoc est civilium librorum, secundus, ab Antonio Montecatino in latinam linguam conversus, et partitionibus, resolutionibus, scholiis illustratus, Ferrariae, apud Benedictum Mammarellum, 1594.

26 Aristotelis, Politica, a Petro Ramo Regio Professore latina facta, et Dialecticis rerum summis breviter exposita \& illustrata. Cum indice rerum \& verborum memorabilium locupletis, Francofurti, typis Weckelianis, apud Claudium Marnium, 1601. 


\begin{tabular}{|l|c|}
\hline $\begin{array}{l}\text { Hubert Von } \\
\text { Giffen, } 1608\end{array}$ & $\begin{array}{l}\text { Omnium vero vitiosissima est potentum petulantia... } \\
\text { potentiorum impotentia \& petulantia... }\end{array}$ \\
\hline Heinsius, 1621 & $\begin{array}{c}\text { Omnium vero vitiosissima est potentum petulantia... licentia } \\
\text { potentum... omnia miscere } \text { ibi solent ac confundere... }\end{array}$ \\
\hline $\begin{array}{l}\text { Conringius, } \\
1656\end{array}$ & Pessimum autem omnium est perturbatio reipublicae... ${ }^{29}$ \\
\hline
\end{tabular}

Firstly, acosmia is translated with the notions of "disorder, confusion", expressed in Latin with the words confusio, perturbatio, conturbatio and turbae. This notion is introduced in the commentary of Jacques Le Fèvre at the beginning of the $16^{\text {th }}$ century with the term turbatio. It is then found constantly in Joachim Périon, Sepulveda, Vettori, Lambin, Louis Le Roy, Montecatini, Pierre de la Ramée, Heinsius and Conringius. One should note that the complement in the genitive of perturbatio or confusio is not the powerful but the entire state (reipublicae, status reipublicae) or the public affairs in general (rerum, rerum civitatis, omnium rerum), terms that are not in Aristotle's original text.

Secondly, the term acosmia is understood with the notions of "licentiousness, intemperance, impudence, insolence, excess", expressed by the Latin words licentia, immodestia, petulantia and impotentia, so many terms that designate moral vices of the powerful. This interpretation appears in the commentary of Joachim Camerarius at the end of the $16^{\text {th }}$ century with the term licentia. It is taken up in Montecatini, Hubert von Giffen and Heinsius. In this interpretation, the complement in the genitive is potentum: it relates indeed to the misconduct of the powerful.

This interpretation is not opposing the first one, since the vices of the powerful are perceived as the cause of disorder in the respublica. It appears clearly in Montecatini's commentary which reconciles the two interpretations: immodestiam ac petulantiam potentum, ex qua turbae nascuntur, "the excess and the insolence of the powerful that give birth to troubles".

On the whole, these translations and commentaries are clearly

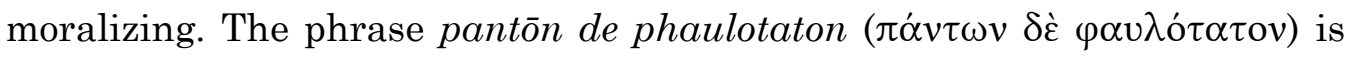
most often understood, not as the worst of remedies referring to the term employed previously (Denis Lambin: omnium remediorum pessimum), but

27 Oberti Giphanii, Commentarii in Politicorum opus Aristotelis, post sat bene longam suppressionem, jam, boni publici gratia, primum in lucem editi, Francofurti, impensis Lazari Zetzneri, 1608.

28 Aristotelis, Politicorum, Libri VIII, com perpetua Danielis Heinsii in omnes libros paraphrasi accedit accuratus rerum index, Lugduni Batavorum, ex officina Elzeviriana, 1621.

29 Aristotelis, Politicorum libri superstites, editio nova cura Hermanni Conringii cum ejusdem Introductione \& Emendationibus, Helmestadii, Typis \& sumptibus Henningi Mulieri, Academiae Typographi, 1656. 
as the worst of all vices and all sins (omnium vitiorum, peccatum omnium). Sometimes the superlative phaulotaton is translated directly by vitiosissima.

How can we explain this choice of translation? The first explanation rests on the reference to ancient texts which are then rediscovered. In his commentary, Pietro Vettori supports his interpretation by referring to Aeschines' use of the term in Against Ctesiphon: the acosmia of the powerful must be understood as the misbehavior of orators disparaged by Aeschines. Their acosmia is characterized by their lack of ratio and modestia. The second explanation rests on the reference to their own time orienting their reading. Antonio Montecatini, for instance, explains the disorder of the powerful as one of the three ways that exist, in reference to his own time, to escape justice, the two others being trickery and corruption.

Is this interpretation actually corroborated by the uses of the term acosmia in Aristotle's time? The term acosmia formed with the negative

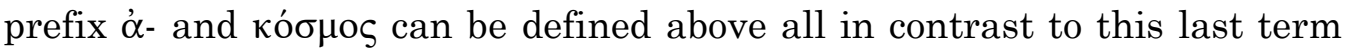
that denotes "good order", in a material or moral sense (good behavior, discipline, propriety, decency, modesty). ${ }^{30}$ A definition is given by Gorgias in the captatio benevolentiae of his Encomium of Helen:

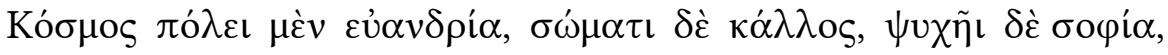

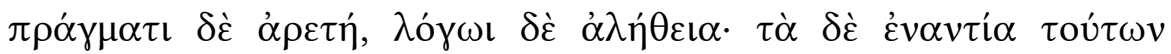
$\dot{\alpha} \kappa о \sigma \mu i \alpha$.

The right order for a city is being well-manned; for a body, beauty; for a soul, wisdom; for a deed, virtue; and for a speech, truth; the opposites of these are disorder.

Gorgias, Encomium of Helen, 1.1-331

Correlatively, the concept of acosmia has a wide extension. It includes a broad range of moral defects. The examination of the term's occurrences ${ }^{32}$ shows two main uses in Aristotle's time. On the one hand, it designates, in a philosophical and cosmological use, the material disorder of elements, chaos as opposed to the harmonious order of elements in the universe. ${ }^{33}$ On the other hand, it designates often, in the private or social sphere, with a moral

30 Cf. Chantraine 1968, 570-571.

31 DK 82[76] B 11 (II, 288, 2-4).

32 The corpus under examination includes the 25 occurrences given by the TLG from the origins to the $1^{\text {st }}$ century $\mathrm{BC}$ and the numerous occurrences in Plutarch's work (17 occurrences).

33 Plato, Gorgias, 508a4, Symposium, 188b4 ; Plutarch, Life of Dion, 10, 2, De animae procreatione in Timaeo, 1014b6, De defectu oraculorum, 430e5, Quaestiones conviviales, 646a1, De facie quae in orbe lunae apparet, $926 \mathrm{e} 3$. 
dimension, the behavior of someone who doesn't stay in his place, who doesn't respect moral values and social rules, who is immoderate, excessive, outrageous, inordinate... ${ }^{34}$ This is the meaning within which acosmia could be understood in our passage. Besides this unique occurrence of the substantive acosmia in Aristotle's work, ${ }^{35}$ the verb acosmō ( $\left.\dot{\alpha} \kappa о \sigma \mu \dot{\varepsilon} \omega-\tilde{\omega}\right)$ is used in the Athenian Constitution, III 6, to designate the troublemakers, those who disrupt public order because of their disrespectful and bad

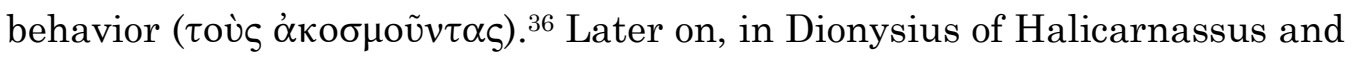
Plutarch, the term designates often the disorder of a crowd (assembly, spectators or army) combining the material and moral dimensions, in a political and military context. ${ }^{37}$

What are the limits of this interpretation? First, the syntactic structure doesn't allow a satisfactory translation (acosmia is constructed as direct object of kathistasi ( $\kappa \alpha \theta \iota \tau \tilde{\alpha} \sigma \mathrm{\iota})$, "the misbehavior that they established"). What's more, the context leads to consider another meaning, the one of abeyance of Cosmi, which was the common understanding in Medieval time.

\section{b. Acosmia as vacancy of the office of Cosmi}

\begin{tabular}{|l|l|}
\hline $\begin{array}{l}\text { William of } \\
\text { Moerbeke, ca } \\
1260\end{array}$ & $\begin{array}{l}\text { Q.i.: Omnium autem pessimum quod akomie, quam constituunt } \\
\text { frequenter, cum non causas velint dare potentum / Q. : Omnium autem } \\
\text { pessimum id quod Acosmiae quam constituunt frequenter, cum non } \\
\text { sententias velint dare potentum. } 38\end{array}$ \\
\hline $\begin{array}{l}\text { Omnium autem pessimum Acosmiae, ab d quod est sine, et koouí, } \\
\text { Magnus, ca } \\
1275\end{array}$ & $\begin{array}{l}\text { quod est violenta cessatio Cosmorum quando scilicet cogebantur } \\
\text { cedere [...] quando Cosmi, qui judices sunt, nolunt dare sententias pro } \\
\text { potentibus, et tunc conspirantes dejiciunt eos [...] acosmia, id est, } \\
\text { cessatio potentatus Cosmorum... }\end{array}$ \\
\hline
\end{tabular}

34 Sophocles quoted by Plutarch, Conjugalia praecepta, 26, 141e5; Euripides, Iphigenia in Aulis, v.317; Aeschines, Against Timarchus, 169, 9 and 189, 8, Against Ctesiphon, 4, 7; Plutarch, Life of Sertorius, 26, 9, Life of Antony, 11, 4, Consolatio ad uxorem, 609e2; Dionysius of Halicarnassus, Roman Antiquities, VII, 23, 3 and XVI, 4, 3; cf. also Cassius Dio, Roman History, 54, 16, 3.

${ }^{35} \mathrm{I}$ am not taking into account here the late treaties attributed to Aristotle.

36 The participle is often used as noun to designate people disrespectful of moral or social order in the private or public sphere, cf. Plato, Laws, 764b6, 784d7, 785a2.

37 Dionysius of Halicarnassus, Roman Antiquities, I, 85, 1, VI, 34, 3, VI, 65, 3, VI, 66, 2, VII, 35, 4, VIII, 15, 2, IX, 53, 4, X, 41, 1, XX, 12, 3, De Isocrate 8, 7 and 9, 55 ; Plutarch, Life of Cicero, 13,4, Life of Crassus, 24, 4 and 27,7, Life of Otho, 13, 5, Life of Galba, 15, 3, Life of Cato the Younger, 63, 1, Life of Coriolanus, 18, 5.

38 Aristoteles Latinus, XXIX I Politica (libri I-II.11) Translatio prior imperfecta interprete Guillelmo de Moerbeka, edidit Petrus Michaud-Quantin, Bruges-Paris, Desclée de Brouwer, 1961. Aristotelis, Politicorum libri octo, cum vetusta translatione Guilelmi de Moerbeka. Recensuit Franciscus Susemihl. Accedunt variae lectiones Oeconomicorum, Lipsiae, in aedibus Teubneri, 1872.

39 B. Alberti Magni, ratisbonensis episcopi, ordinis praedicatorum, Opera omnia, ex editione lugdunensi religiose castigata, cura ac labore Augusti Borgnet, Volume octavum, 


\begin{tabular}{|c|c|}
\hline $\begin{array}{l}\text { Thomas } \\
\text { Aquinas, ca } \\
1272\end{array}$ & $\begin{array}{l}\text { cessatio principatus Cosmorum : interdicebant enim ad tempus } \\
\text { omnino talem principatum : hoc autem dicit esse pessimum, quia non } \\
\text { solum erat contra personas, sed contra totum officium vel principatum ex } \\
\text { quo proveniebat multa utilitas civitati. } \\
\quad \text { de vacatione Cosmorum... }\end{array}$ \\
\hline $\begin{array}{l}\text { Nicole Oresme, } \\
\text { ca } 1372\end{array}$ & $\begin{array}{l}\text { Et de toutes les ordenances que il ont ce est la tres plus malvese que } \\
\text { celle que il appellent akosme, ce est a dire estre sans kosme. Et est } \\
\text { cessacion du fait et de la juridiction que avoient ceulz qui sunt diz } \\
\text { kosmoys. Et establissent tele chose quant il ne veullent pas que l'en donne } \\
\text { sentences contre aucuns puissans hommes. }{ }^{41}\end{array}$ \\
\hline $\begin{array}{l}\text { Leonardo } \\
\text { Bruni } \\
\text { d'Arezzo, 1436- } \\
1438^{42}\end{array}$ & $\begin{array}{l}\text { potentum depositio...potentium ab cosmatu depositio: quae } \\
\text { saepe concitant, cum non sententias dare volunt }\end{array}$ \\
\hline $\begin{array}{l}\text { Jacques Le } \\
\text { Fèvre } \\
\text { d'Etaples, } \\
\text { 1506-151143 }\end{array}$ & $\begin{array}{l}\text { Quia omnium deterrima turbatio : ipsorum potentum ab Cosmatus } \\
\text { dignitate depositio... }\end{array}$ \\
\hline
\end{tabular}

In the first Latin translation, in the $13^{\text {th }}$ century, W. of Moerbeke, who translates word by word, transliterates the Greek term without clarifying its meaning. However from the first commentaries, the term was understood as referring to the vacancy of the office. The Greek word acosmia is explained by the Latin words cessatio and vacatio, in Albertus Magnus, Thomas Aquinas and Nicole Oresme. In the new Latin translation by Leonardo Bruni in the $15^{\text {th }}$ century, acosmia is translated into the term depositio, taken up by Jacques Le Fèvre.

The text commented by Albertus Magnus and Thomas Aquinas and translated by Nicole Oresme in French, is the Latin translation by W. of Moerbeke. The latter places the term potentum at the end of the sentence. Nevertheless, the powerful are understood as the subject of constituunt: the powerful cause the departure of the Cosmi when the latter don't want to

Politicorum Lib. VIII, Commentarii in octo libros politicorum Aristotelis, Parisiis, Apud Ludovicum Vivès, 1891.

40 S. Thomae Aquinatis, In libros Politicorum Aristotelis expositio, cura et studio P. F. Raymundi M. Spiazzi, Taurini, Marietti, Romae, 1951. Politica Leonardo Aretino interprete, cum commentariis Thomae de Aquino et conclusionibus Ludovici Valentiae, Silber Eucharius imp., 1492. Tomus quintus D. Thomae Aquinatis doctoris angelici, complectens expositionem, in decem libros Ethicorum, et in octo libros Politicorum Aristotelis, 1570.

41 Oresme, Le livre de politiques d'Aristote, Paris, chez Antoine Vérard, 1489. Maistre Nicole Oresme, Le Livre de politiques d'Aristote, published from the text of the Avranches Manuscript 223, with a critical Introduction and Notes by Albert Douglas Menut, TAPhS, 60, 6, 1970. Oresme's Livre de Politiques and the France of Charles V, Susan M. Babbitt, TAphS, 75, 1, 1985 (Chapter II " Oresme and the commentary tradition of the Politics », p.14-31).

42 Aristoteles Stagiritae, Libri moralem totam philosophiam complectentes, tertium volumen, Venetiis apud Iuntas, 1550.

43 In hoc libro contenta: Politicorum [Aristotelis] libri octo; commentarii [Jacobi Fabri Stapulensis in eosdem]; Economicorum duo; Commentarii [Fabri]; Hecatonomia septem; Economiarum publicarum unus; Explanationes Leonardi [Aretini] in Oeconomica duo, Parisiis, ex officina Simonis Colinaei, 1543. 
deliver judgments on their behalf. Nicole Oresme's commentary remains unspecified with the pronouns "ils" and "on": "they establish acosmia when they do not want judgments to be pronounced against the powerful".

From the translation of Leonardo Bruni onwards, potentum appears as the complement in the genitive of acosmia. Leonardo Bruni translates potentium ab cosmatu depositio quae saepe concitant cum non sententias dare volunt ("the deposition of the powerful from the office of Cosmi that they often cause when they do not want to issue judgments"). In this translation, the powerful are equated with the Cosmi and the meaning is ambiguous, leaning towards deposition (depositio) or resignation (quae saepe concitant).

However, this sense is progressively eclipsed by the one of disorder during the $16^{\text {th }}$ century. It is only in the $19^{\text {th }}$ century that it is reintroduced in Gottlob Schneider's edition of 1809. The latter establish a parallel between acosmia and anarchia. This interpretation is then adopted by translators up to our time.

What is this interpretation by the first commentators and translators based on? On the one hand, it relies on the morphological analysis and the

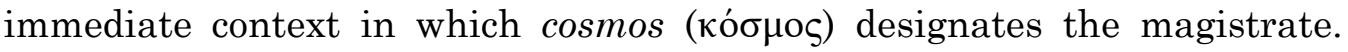
Thus, Albertus Magnus analyses the term : ab \& quod est sine, et коoнía, quod est violenta cessatio Cosmorum. This analysis is resumed in the next century in the French translation by Nicole Oresme (akosme, ce est a dire estre sans kosme). On the other hand, it is based upon the general meaning of the passage. The abeyance of the power of the Cosmi is explained by the formation of a coalition (conspirantes), the violent action of the powerful who forcibly evict the Cosmi (dejiciunt) and prevent them from holding office (interdicebant, cogebantur cedere), in accordance with the above. Indeed, as Aristotle enumerates different kinds of abeyance (the clause is coordinated by $d e(\delta \varepsilon \dot{)})$ and the superlative phaulotaton ( $\varphi \alpha u \lambda$ ó $\tau \alpha \tau o v)$ draws an axiological comparison with the previous cases), it seems preferable to understand acosmia on the model of anarchia with the institutional sense of office vacancy.

This use can be set alongside Aristotle, Athenian Constitution XIII, 1, aforementioned. The Athenians didn't appoint an Archon twice. The phenomenon is described first with the clause ou katestēsan archonta (oủ $\kappa \alpha \tau \dot{\varepsilon} \sigma \tau \eta \sigma \alpha \nu$ " $\rho \chi 0 \nu \tau \alpha$, “they didn't appoint an Archon", 1.2), and then with

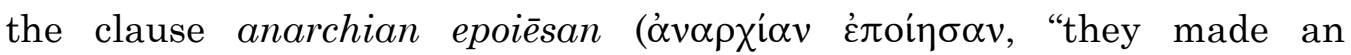
anarchia", 1.3). These phrases find an echo with tēs akosmias hēn kathistasi

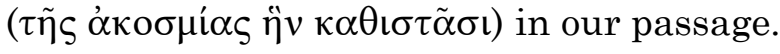

It should be understood that the powerful, the noble Cretans who want to evade justice, establish acosmia, that is to say, suspend the office either by preventing the Cosmi from holding their office or by not proceeding to 
their appointment, with the result that there is no office holder to fulfill its functions and the dispensation of justice is suspended. ${ }^{44}$

From then on, what is the difference between acosmia and the two cases aforementioned? In my opinion, the three cases have as a consequence the abeyance of Cosmi and so the possibility to escape prosecution. But, as suggested by Thomas Aquinas, non solum erat contra personas, sed contra totum officium, ex quo proveniebat multa utilitas civitati, "it was not only against individuals, but against all the magistracy, which was highly beneficial to the political community". In the third case, the very institution of the office of Cosmi is threatened. A part of the constitution is abolished giving free rein to arbitrariness and individual will. This distinctive feature is, in my opinion, the reason why Aristotle characterizes this third case as the worst and presents it as the proof that the Cretan constitution is not in its essence political but dynastic. Therefore, it is now necessary to consider the consequences of acosmia on the political regime.

\section{THE CONSEQUENCES OF ACOSMIA}

\section{a. The first consequence: the transformation of the regime's nature into a $\delta v v \alpha \sigma \tau \varepsilon i \alpha$}

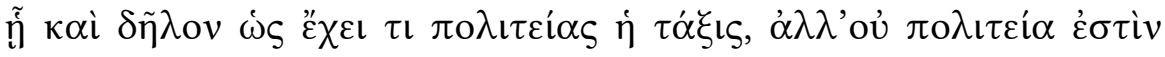
$\dot{\alpha} \lambda \lambda \dot{\alpha} \delta v v \alpha \sigma \tau \varepsilon i \alpha \mu \tilde{\alpha} \lambda \lambda o v$.

That shows also that the organization has something of a constitution but is not a constitution but rather a dynastic government.

The term taxis ( $\tau \alpha^{\prime} \xi ı$ เ ) is used by Aristotle in the Politics to designate the organization of the different components of the city, but especially the organization of the politeia $\left(\pi \mathrm{o} \lambda \mathrm{\imath} \tau \varepsilon \varepsilon^{\prime} \alpha\right)^{45}$ itself, that is to say, the partition of citizens and the distribution of power. ${ }^{46}$ It determines the politeia ${ }^{47}$ and defines it as a democracy, an oligarchy or a monarchy... ${ }^{48}$ This order is inseparable from law (nomos, vó $\mu$ os), insofar as an organization is a law, a

\footnotetext{
44 Schütrumpf's translation, "die Amtsgewalt der Kosmoi außer Kraft setzen" (Schütrumpf 1991, 42) may imply that the Cosmi are deprived of their power but stay in place, which is, in my view, not the case.

45 On Aristotle's concept of politeia, cf. Schütrumpf 1991, p.342, Hansen 2013.

46 Cf. Aristotle, Politics, 1253a38, 1264b31; 1268a15; 1269a10; 1271b41; 1272a4; 1272b31; 1281b39; 1289a1; 1296a40; 1297b28; 1307b18; 1309b33; 1316b32; 1318b36; 1325a3; 1329b33; $1333 \mathrm{~b} 7$.

${ }^{47}$ Cf. Aristotle, Politics, 1274b38, 1278b9, 1289a15, 1290a8, 1324a24, 1309b33, $1272 \mathrm{~b} 31$.

48 Cf. Aristotle, Politics, 1265b26, 1273a21, 1273a27, 1294b21, 1298 b5.
} 
law is an organization and a good organization goes along with good laws, ${ }^{49}$ knowing that laws must be established according to the kind of politeia. ${ }^{50}$

The Cretan practice described by Aristotle is characterized from the

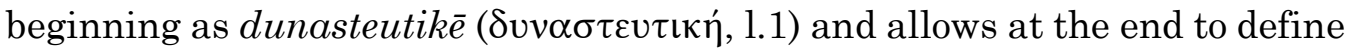
the regime's nature as a dunasteia ( $\delta v v \alpha \sigma \tau \varepsilon i \alpha, 1.6),{ }^{51}$ that is, the fourth and extreme form of oligarchy in Aristotle's classification, corresponding to the extreme form of democracy and the extreme form of monarchy, i.e. tyranny. ${ }^{52}$ Its distinctive feature is that power is concentrated into the hands of a minority of citizens whose great power is based on wealth and friendship relations, inherited and exercised independently of laws. ${ }^{53}$ In several passages, Aristotle explains how a dunasteia is formed. ${ }^{54}$ Two specific explanations tally with our passage. A dunasteia appears notably either when a small group of persons holds too much power ${ }^{55}$ or when constitutional provisions are progressively repealed and a few individuals then govern arbitrarily. ${ }^{56}$ Aristotle also indicates that this extreme form of oligarchy, whose causes of troubles and seditions are so numerous, is the most unstable and the most difficult to preserve (cf. below the third consequence). ${ }^{57}$

According to Aristotle, the extreme forms of government, which are tyrannical regimes of private rule, lose their constitutional value ${ }^{58}$ because power isn't based on law anymore but on the arbitrary will of the rulers (ö $\pi$ ov

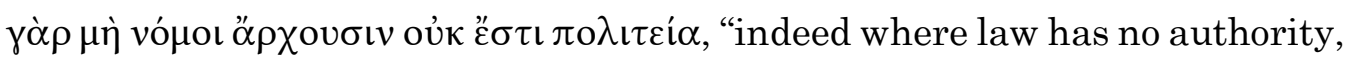
there is no constitution at all”, IV 1292a32). ${ }^{59}$ To avoid arbitrary power and personal domination, it is necessary that law rules, defining the distribution and exercise of power and being the condition of a true politeia. Extreme forms of regime lead to the dissolution of legally established powers and thereby defined and limited. ${ }^{60}$ As a comparison, extreme democracy, which appears when the Assembly holds a despotic power, leads to the ruin of all

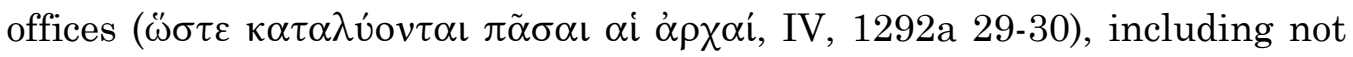

49 Cf. Aristotle, Politics, 1287a18, 1326a30, 1269a32.

50 Cf. Aristotle, Politics, 1289a13-20.

51 Chantraine 1968, 301: this word family refers to a violent, arbitrary and unconstrained power. On the use of $\delta v v \alpha \sigma \tau \varepsilon i \alpha$ and $\delta v v \alpha \tau o$, cf. Tricot 1962, p.150, Caire 2016, 55-57, 152-153.

52 Cf. Aristotle, Politics, 1298 a32.

${ }^{53}$ Cf. Aristotle, Politics, IV, 5, 1292b10, IV, 6, 1293a31.

${ }^{54}$ Cf. Aristotle, Politics, V, 3, 1302b18, 1303a13, V, 8, 1308b8, V, 6, 1306a24, V, 7, 1307b18, $\mathrm{V}, 8,1308 \mathrm{a} 18$.

55 Cf. Aristotle, Politics, V, 3, 1302b18, V 6 1306a15.

${ }^{56}$ Cf. Aristotle, Politics, V, 7, 1307b18.

57 Cf. Aristotle, Politics, VI, 6, 1320 b31.

${ }^{58}$ Cf. Aristotle, Politics, IV, 8, 1293b27-29.

59 Cf. Newman 1887, 358-359, Schütrumpf 1991, 342, Curnis \& Pezzoli 2012, 356.

60 Cf. Curnis \& Pezzoli 2012, 356 speaking about "il venir meno dei poteri legittimi, ovvero la legge e l'istituzione del cosmato“. 
only the power of magistrates but also the power of the Council and the power of laws.

In the Cretan regime, power is excessively concentrated in the hands of a few, being accountable to no one and following their goodwill rather than obeying the law. The officials legally appointed are very often deprived of their power and the office itself is often abolished by the powerful who then govern as masters. These practices are usual ( $\varepsilon \dot{i} \omega \theta \alpha \sigma \iota, \pi 0 \lambda \lambda \dot{\alpha} \kappa \iota \varsigma$ repeated twice). They are therefore constitutive and characteristic of this regime and transform its nature.

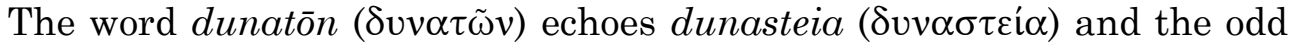

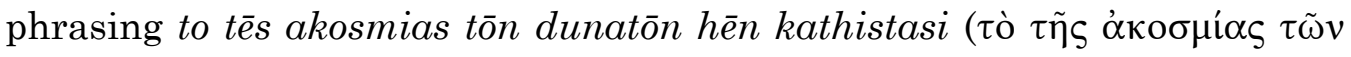
$\delta v v \alpha \tau \tilde{\omega} v \ddot{\eta} v \kappa \alpha \theta \iota \sigma \tau \tilde{\alpha} \sigma \mathrm{l})$ is as much striking as it expresses all the paradox of this constitution that is not one, where the powerful by "establishing" acosmia, prevent the lawful exercise of power by the Cosmi and thereby abolish the politeia.

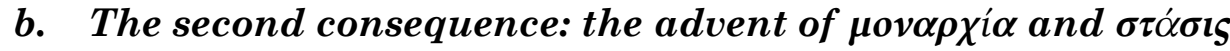

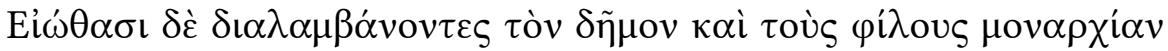

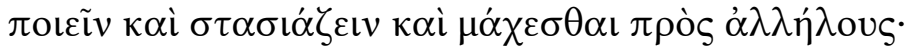

It is their custom, by dividing the people and their friends, to establish a monarchy, to form factions and to fight the ones against the others.

Once the lawful government is abolished, the powerful divide the city and fight against each other. Here occurs another philological problem: the word monarchia ( $\mu$ ov $\alpha \rho \chi i \alpha)$ of the manuscripts is sometimes replaced by the word anarchia (anarchy), as anarchy seems more compatible with the notions of division and civil war ${ }^{61}$. In my opinion, it is preferable to keep the text of the manuscripts.

61 This correction attributed to J. Bernays has been adopted by Susemihl 1894, Immisch 1909, Goold 1932, Ross 1957, Tricot 1962, Laurenti 1966, Pellegrin 1990, Robledo 2000. In favor of anarchia cf. Schütrumpf 1991, p.343: the establishing of a monarchia is contradictory with the idea that the politeia is abolished, moreover Aristotle doesn't usually use the verb poien to denote the establishing of a constitution. One may consider that Aristotle is not so much referring to monarchia as a constitution but to single-man powers and the "arbitrary despotism of the powerful families" (cf. Barker 1961 ("set up...as many monarchies"), Aubonnet 1960 ("susciter comme des monarchies"), Simpson 1998, p.123, Curnis \& Pezzoli 2012, p.357), cf. Plato's dunasteia in Laws, III, 680b. Nevertheless Aristotle does not use a comparative term and "monarchy" is in the singular. 
Besides the parallel established by Newman with the narrative of Herodotus about the advent of Peisistratos' tyranny in a situation of stasis, ${ }^{62}$ the Aristotelian context appears to be close, by its wording and idea, to the elegies of Theognis of Megara ( $6^{\text {th }}$ century BC). At the beginning of book I, v.39-42 and 51-52, ${ }^{63}$ Theognis expresses the fear, in a situation of stasis, of the advent of a tyrant, to straighten the situation ( $\alpha \nu \delta \rho \alpha \varepsilon \dot{v} \theta v v \tau \tilde{\eta} \rho \alpha$, v.39-

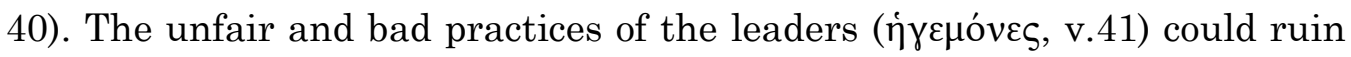
the city by engendering divisions into factions ( $\sigma \tau \dot{\alpha} \alpha \sigma^{\prime} \varepsilon$ ), murders among

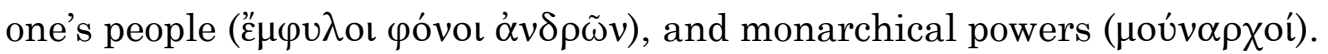

When there is no more lawful established government, that is in a situation of anarchia or here of acosmia, it is the advent of a monarchical, authoritarian and arbitrary power that is feared. We can draw a parallel with Aeschylus in The Eumenides and his warnings against the double danger of anarchia and despotism when the laws are not obeyed, ${ }^{64}$ or with Plato and his description of the transformation of democracy - presented as a regime of anarchia ${ }^{65}$ - into tyranny in the Republic, VIII-IX.

\section{c. The last consequence of this practice: the dissolution of the political community}

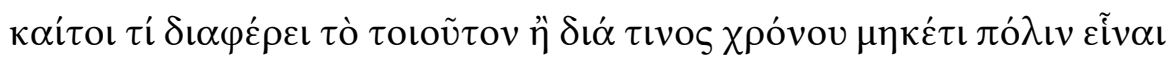

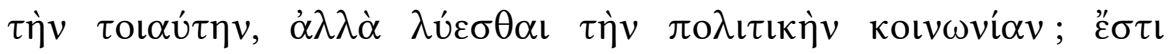

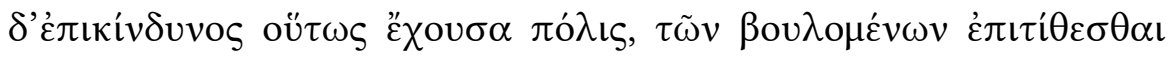
$\kappa \alpha i ̀ ~ \delta v v \alpha \mu \varepsilon ́ v \omega v$.

However, how such a situation differs from the fact that for some time such a city doesn't exist anymore and the political community is dissolved? A city that stands in this way is in danger, because those who want to attack it also have the power to do it.

\footnotetext{
62 Newman 1887, p.359. One should note also that Aristotle establishes a close link between dunasteia and monarchia: when the powerful concentrate excessive power, fortune or friends, appears a dunasteia close to monarchia (IV, 1293a30-34) or even a monarchia (V, 1302b18). One can understand as well in a figurative way that the powerful impose their will as a monarch in the same way as the people in the extreme form of democracy govern as a

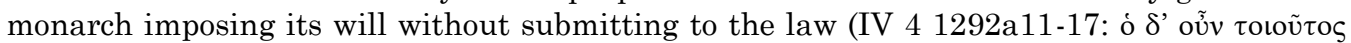

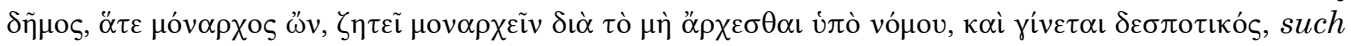
a people, as being monarch, seeks to exercise monarchic rule through not being ruled by law and he becomes despotic). In both cases, the law is abolished and the power becomes despotic; nevertheless in the case of the dunasteia it is more difficult to conceive a unity in comparison to the demos governing with one voice through decrees.

63 Carrière 1975.

64 Aeschylus, Eumenides, v.525-527, v.696-697.

65 Plato, Republic, VIII, 558c3-7, 560d3-561a4, 562c9-562e5.
} 
According to Aristotle, these periods, characterized by the acosmia, the tyrannical action of the powerful and the civil strife, equate with the

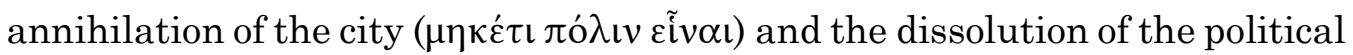

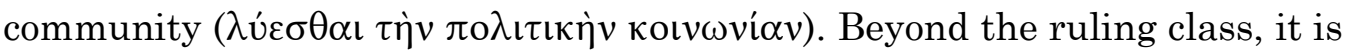
the whole city as a political community that is destroyed. The city deprived of its politeia loses the bulwark of laws and magistrates ensuring their implementation $^{66}$ and becomes thereby extremely vulnerable, dunamenōn $(\delta v v \alpha \mu \varepsilon \dot{\varepsilon} v \omega v)$ echoing in its turn dunasteia and tōn dunatōn ( $\tau \tilde{\omega} v \delta v v \alpha \tau \tilde{\omega} v)$ to designate the almighty power of brute, arbitrary and authoritarian force.

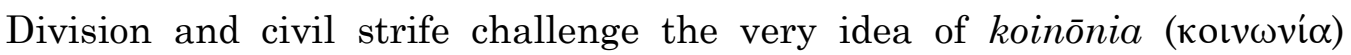
uniting the citizens of the same city.

This consequence appears all the more worrying and serious as Aristotle defines from the beginning of his work the city or the political community ${ }^{67}$ as the highest natural community aiming the supreme good. ${ }^{68}$ It allows not only to "live" but to "live in a good way", ${ }^{69}$ that is to say, to achieve happiness,${ }^{70}$ by fulfilling one's nature of "political animal". ${ }^{71}$ Moreover, the function of the citizen that defines its virtue is to ensure the safety of the community, that is to say, of the politeia, ${ }^{72}$ and not to attack and annihilate it. Therefore a man who acts in such a way acts against his own nature.

\section{CONCLUSION}

Thus, after close examination, it seems to me that the meaning that should be given to acosmia in this passage by Aristotle is the one of "vacancy of the office of Cosmi". However, the fact remains that, due to the word's usual meaning, the notions of misbehavior, impropriety, licentiousness and disorder remain present in the spirit of the reader and enrich the reading of the passage at a second level. The threshold is soon crossed between the institutional meaning of "abeyance of Cosmi" and "disorder" or "disorderly conduct", all the more as the Cosmos is precisely in charge of cosmein

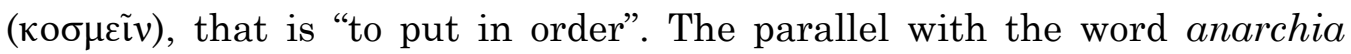
supports this reading on two different levels. Indeed its meaning oscillates in classical Greek sources between absence of government and disorder resulting from the absence of government, state of lawlessness.

Cretan acosmia is comparable to anarchia in the Athenian Constitution: both happen in a situation of division and fight for power between the

\footnotetext{
${ }^{66}$ Cf. Aristotle, Politics, IV, 1289a18-20.

67 Cf. Aristotle, Politics, II, 1, $1260 \mathrm{~b} 40$.

68 Cf. Aristotle, Politics, I, 1, 1252a1-7.

69 Cf. Aristotle, Politics, I, 2, 1252b27-30.

70 Cf. Aristotle, Politics, VII, 8, 1328a35-1328b2.

${ }^{71}$ Cf. Aristotle, Politics, I, 2, 1253a1-5.

72 Cf. Aristotle, Politics, III, 3, 1276b27-31.
} 
powerful in an oligarchic regime. The main difference is that anarchia in Athens happens in an exceptional situation of crisis, whereas in Crete acosmia has become according to Aristotle an usual practice of the powerful so as to escape retribution, to dominate personally and to act according to their goodwill. Consequently, it corrupts the nature of the regime and leads ultimately to the dissolution of the political community and the temporary destruction of the city.

The text variants transmitted by the manuscripts may be a testimony of the difficulties of interpretation already raised by this passage in ancient time, in particular due to the uncommon use of the word acosmia in this sense. One can wonder whether this use was forged by Aristotle on the model of anarchia or whether the word was used in the Cretan cities that had Cosmi as magistrates, use for which, as far as I know, no trace remains.

\section{REFERENCES}

Aubonnet, Jean (ed.). 1960. Aristote, Politique, I, Livres I et II, texte établi et traduit par J. A. Paris: Les Belles Lettres, 1991.

Barker, Ernest. 1961. The politics of Aristotle, transl. with an introd., notes and appendixes by E. B. Oxford: the Clarendon Press.

Bekker, I. (ed.). 1831. Aristotelis opera. Volumen alterum, ex recensione Immanuelis Bekkeri; ed. Academia regia borussica; ed. altera quam curavit Olof Gigon. Berolini: W. de Gruyter, 1970, fac-sim. G. Reimer, 1831.

Bernays, Jacob. 1872. Aristoteles' Politik. Erstes, zweites und drittes Buch, mit erklärenden Zusätzen ins Deutsche uebertragen von Jacob Bernays. Berlin: W. Hertz.

Besso, G. \& Curnis, M. (eds.) 2011. Aristotele, La Politica. Libro I. Roma: L'Erma di Bretschneider.

Caire, Emmanuèle. 2016. Penser l'oligarchie à Athènes aux Ve et IVe siècles. Aspects d'une idéologie. Paris: les Belles Lettres.

Carrière, J. (ed.). 1975. Théognis, Poèmes élégiaques, texte établi, traduit et commenté par Jean Carrière. Paris: les Belles Lettres.

Chaniotis, A. 2005. "The Great Inscription, Its Political and Social Institutions and the Common Institutions of the Cretans." In La Grande iscrizione di Gortyna, edited by Emanuele Greco \& Mario Lombardo, 175-194. Atene: SAIA.

Chantraine, Pierre. 1968. Dictionnaire étymologique de la langue grecque, histoire des mots. Paris: Klincksieck, 1999.

Curnis, M. \& Pezzoli, F. (eds.). 2012. Aristotele, La Politica, II. Roma: L’Erma di Bretschneider. 
Diels, H. \& Kranz, W. (eds.) 1952. Die Fragmente der Vorsokratiker, vol. 2, 6th edn. Berlin: Weidmann.

Dreizehnter, A. (ed.) 1970. Aristoteles' Politik. Eingeleitet, kritisch herausgeben und mit Indices versehen von A.D. München: W. Fink Verlag.

Dreizehnter, A. 1962. Untersuchungen zur Textgeschichte der aristotelischen Politik. Leiden: E.J. Brill.

Gehrke, H.-J. 1997. "Gewalt und Gesetz. Die soziale und politische Ordnung Kretas in der Archaischen und Klassischen Zeit." Klio 79: 23-68.

Goold G. P. (ed.) 1932. Aristotle. XXI. Politics, with an english translation by H. Rackham. Cambridge: Harvard University Press, 1990.

Guizzi, Francesco. 2005. "Partecipano tutti all'assemblea che però non ha alcun potere... La politica ai tempi della grande Iscrizione di Gortyna.” In $L a$ Grande iscrizione di Gortyna, edited by Emanuele Greco \& Mario Lombardo, 99-114. Atene: SAIA.

Hansen, M.H. 2013. Reflections on Aristotle's Politics. Copenhagen: Museum Tusculanum Press.

Immisch Otto (ed.). 1909. Aristotelis, Politica, post Fr. Susemihlium recognovit Otto Immisch. Lipsiae: B. G. Teubner.

Lanza, L. 2013. Ei autem qui de politia considerat ... Aristotele nel pensiero politico medievale. Barcelona and Madrid: Fédération des Instituts d'Études Médiévales.

Laurenti, Renato. 1966. Aristotele, La Politica. Bari: Laterza.

Link, S. 1994. Das Griechische Kreta. Untersuchungen zu seine staatlichen und gesellschaftlichen Entwicklung vom 6. bis zum 4. Jahrhundert v. Chr. Stuttgart: Franz Steiner.

Link, S. 2003. "Kosmoi, Startoi und Iterationsverbote.” Dikè 6: 139-149.

Mathieu, Georges \& Haussoullier, Bernard (eds.). 1985. Aristote, Constitution d'Athènes. Paris: Les Belles Lettres.

Newman, W. L.1887. The Politics of Aristotle. Salem (N.H.): Ayer Company publ., facsim. 1985.

Papakonstantinou, Zinon. 2002. "Written Law, Literacy and Social Conflict in Archaic and Classical Crete." AHB 16: 135-150.

Pellegrin, Pierre. 1990. Aristote, Les Politiques, traduit par P. P. Paris: Flammarion.

Perlman, Paula. 1992. "One-hundred Citied Crete." CPh 87: 193-205.

Perlman, Paula. 2002. "Gortyn. The First Seven Hundred Years. Part II. The Laws from the Temple of Apollo Pythios." In Even More Studies in the Ancient Greek Polis, edited by Th. H. Nielsen, 187-227. Stuttgart: Franz Steiner.

Pouilloux, Jean. 1954. Recherches sur l'histoire et les cultes de Thasos, I, De la fondation de la cité à 196 avant J.C., EfA, Etudes Thasiennes, III. Paris: E. de Boccard.

Robledo, Antonio Gómez. 2000. Aristóteles, Política. México: Universidad nacional autónoma de México, $2^{\text {nd }}$ ed. 
Ross, W. D. (ed.) 1957. Aristotelis Politica, New York: Oxford University Press, 1992.

Ruzé, Françoise. 1997. Délibération et pouvoir dans la cité grecque de Nestor à Socrate. Paris: Publications de la Sorbonne.

Schmitt, Charles. 1992. Aristote et la Renaissance, trad. de l'anglais et présenté par Luce Giard. Paris: Presses universitaires de France.

Schneider G. (ed.) 1809. Aristotelis, Politicorum libri octo superstites. Graeca recensuit, emendavit, illustravit interpretationemque Latinam addidit Io. Gottlob Schneider. Francofurti ad Viadrum: Libraria Academica.

Schütrumpf, E. 1991. Aristoteles, Politik. Buch II-III, übersetzt und erläutert von E.S. Berlin: Akademie-Verlag.

Schütrumpf, E. 2014. The earliest translations of Aristotle's Politics and the creation of political terminology. Paderborn: W. Fink.

Simpson, Peter Phillips. 1998. A philosophical commentary on the Politics of Aristotle. Chapel Hill: University of North Carolina Press.

Susemihl, Franciscus (ed.). 1894. Aristotelis, Politica, tertium edidit, nova impressio correctior. Lipsiae: B. G. Teubner.

Tricot, Jean. 1962. Aristote, La Politique. Paris: Vrin (1962, 1995).

Willetts, Ronald. 1955. Aristocratic Society in Ancient Crete. London: Routledge and Kegan Paul.

Willetts, Ronald. 1967. The Law Code of Gortyn. Berlin: W. de Gruyter. 